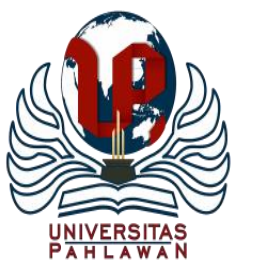

Jurnal Basicedu Volume 3 Nomor 4 Tahun 2019 Halaman 1038-1046

JURNAL BASICEDU

Research \& Learning in Elementary Education

https://jbasic.org/index.php/basicedu

\title{
PENERAPAN STORYTELLING UNTUK MENINGKATKAN KETERAMPILAN BERBICARA DI SEKOLAH DASAR
}

\author{
Desmarita Khairoes1, Taufina ${ }^{2}$ \\ Universitas Negeri Padang, Sumatera Barat, Indonesia ${ }^{1,2}$ \\ Email: desmaritakhairoes099@gmail.com ${ }^{1}$, taufina taufik@yahoo.co.id ${ }^{2}$
}

\begin{abstract}
Abstrak:
penelitian ini bertujuan untuk meningkatkan keterampilan berbicara siswa dan membantu siswa kelas I SDN 02 Koto Tangah Batu Ampa. Penelitian ini menggunakan Storytelling. Jenis penelitian ini adalah penelitian tindakan kelas yang dilaksanakan dalam 2 siklus yang terdiri atas kegiatan awal, kegiatan inti, dan kegiatan akhir. Teknik pengumpulan data menggunakan observasi, catatan lapangan, dan dokumentasi. Analisis data menggunakan kualitatif dan kuantitatif. Hasil penelitian menumjukkan terdapat penimgkatan kemampuan berbicara melalui storytelling bahwa pada tindakan siklus I dari 25 oarang peserta didik yang tuntas $60 \%$. dan pada siklus II $88 \%$ dengan kategori sangat baik. Hal ini berarti pembelajaran pada siklus II telah memenuhi indikator keberhasilan sehinnga dapat didimpulkan bahwa perbaikan pembelajaran dengan storytelling dapat meningkatkan keterampilan berbicara siwa pada mata pelajaran bahasa Indonesia di kelas I SD Negeri 02 Koto Tangah Batu Ampa.
\end{abstract}

Kata Kunci : Keterampilan Berbicara, Pembelajaran Tematik dan Storytelling.

\begin{abstract}
:
This research aims to improve students' speaking skills and help students of grade I SDN 02 Koto Tangah Batu Ampa. This research uses Storytelling. This type of research is a classroom action research conducted in 2 cycles consisting of initial activities, core activities, and final activities. Data collection techniques using observation, field notes, and documentation. Data analysis uses qualitative and quantitative. The results showed there was an increase in speaking ability through storytelling that in the first cycle of the 25 students $60 \%$ completed. and in the second cycle $88 \%$ with a very good category. This means that learning in cycle II has met the indicators of success so that it can be concluded that the improvement of learning by storytelling can improve students' speaking skills in Indonesian subjects in grade I of SD Negeri 02 Koto Tangah Batu Ampa.

Keywords: Speaking Skills, Thematic Learning and Storytelling
\end{abstract}

@ Jurnal Basicedu Prodi PGSD FIP UPTT 2019

$\bowtie$ Corresponding author :

Address :

Email :

ISSN 2580-3735 (Media Cetak)

Phone ISSN 2580-1147 (Media Online) 
1039 Penerapan Storytelling untuk meningkatkan keterampilan berbicara di Sekolah DasarDesmarita Khairoes, Taufina

\section{PENDAHULUAN}

Pendidikan adalah komponen penting yang harus dimiliki oleh setiap bangsa, termasuk Indonesia. Melalui pendidikan diharapkan terciptalah generasi penerus yang bisa mengharumkan nama bangsa dikancah Internasional. Pendidikan juga merupakan salah satu aspek yang menentukan masa depan bangsa. Undang - undang RI nomor 20 tahun 2003tentang Sistem Pendidikan Nasional (UU Sisdiknas) mengenai tujuan pendidikn nasional yang harus digunakan dalam mengembangkan upaya pendidikan di Indonesia. Pendidikan Nasional brtujuan untuk berkembangnya potensi peserta didik agar menjadi manusia yang beriman dan bertakwa kepada Tuhan Yang Maha Esa, berakhlak mulia, sehat, berilmu, cakap, kreatif, mandiri dan menjadi warga negara yang demokratis serta bertanggung jawab.

Kurikulum merupakan jantungnya pendidikn (Curruculum is The Heart of Education). Sejak Indonesia merdeka, pendidikan telah mengalami berbagai perubahan dan perbaikan kebijakan kurikulum. Dalam sejarah kurikulum di Indonesia Paling tidak telah mengalami sebelas kali dinamika perubahan. Dimulai dari masa prakemerdekaan dengan bentuk yang sangat sederhana, dan masa kemerdekaan yang terus menerus di sempurnakan yaitu pada tahun 1947, 1952, 1964, 1968, 1975, 1984, 1994, 2004, 2006, dan tahun 2013. Berbagai kebijakan perubahan kurikulum tersebut didasarkan pada hasil analisis, evaluasi, prediksi dan berbagai tantangan yang dihadapi baik internal maupun eksternal yang terus berubah. Dalam konteks ini kurikulum sebagai produk kebijakan bersifat dinamis, kontestual, dan relatif(Machali, 2015).

Kurikulum 2013 mengintegrasikan tiga ranah kompetensi yaitu sikap, pengetahuan dan keterampilan yang dalam implementasinya terangkum dalam Kompetensi Inti 1 (KI-1) berupa sikap spiritual, Kompetensi Inti 2 ( KI-2) berupa sikap sosial, Kompetensi Inti 3(KI-3) berupa pengetahuan,dan Kompetensi Inti 4 ( KI-4) berupa Keterampilan(kemendikbud, 2016).

Pembelajaran bahasa Indonesia memiliki peran yang sangat penting bukan hanya untuk membina keterampilan komunikasi saja melainkan juga kepentingan penguasaan ilmu pengetahuan yang lain. Melalui bahasa, peserta didik belajar berbagai pengetahuan yang ada di dunia ini. Dalam konteks ini bahasa digunakan para peserta didik belajar berbagai macam ilmu pengetahuan yang di ajarkan di sekolah(Tambunan, 2017).

Sekolah sebagai wadah dalam prosesbelajar yang mempunyai kedudukan yang amat penting dalam dunia pendidikan. Oleh karena itu, pendidikan di sekolah memegang peran yang sangat penting yaitu dalam rangka mewujudkan pendidikan nasional secara optimalan maksimal seperti apa yang diharapkan selama ini. Dalam proses belajar mengajar di sekolah guru menjadi peran utama dalam menciptakan suatu situasiinteraktif yang bersifat edukatif, yaitu interaksi antara guru dengan peserta didik, 
1040 Penerapan Storytelling untuk meningkatkan keterampilan berbicara di Sekolah DasarDesmarita Khairoes, Taufina

peserta didik dengan peserta didik dan sumber pembelajaran yang dapat menunjang tercapainya tujuan dari belajar.

Dalam pembelajaran di sekolah, keterampilan berbicara diperlukan sebagai alat menyatakan pendapat, gagasan, memberikan informasi atau menerima informasi. Berdasarkan hal di atas, peneliti memilih Storytelling untuk di jadikan sebagai strategi dan salah satu upaya dalam meningkatkan keterampilan berbicara peserta didik di SDN 02 Koto Tangah Batu Ampa yang berjumlah 25 orang belum secara baik ditingkatkan. Padahal keterampilan berbicara sangat penting untuk ditingkatkan dan awal yang cocok dikembangkan keterampilan berbicara yaitu pada masalah pendidikan disekolah dasar (Eko, 2016).

Berdasarkan hasil observasi awal yang dilakukan ditemukan masih rendahnya kemampuan berbicara peserta didik. Dan hasil observasi kegiatan yang dilakukan dalam kelas, guru masih kurang dalam melakukan kegiatan bervariasi dalam kegiatan pembelajaran. Pentingnya aktivitas yang dapat muncul rasa ingin tahu peserta didik, pengalaman sensori dan mengeksplorasi ide akan dapat meningkatkan motivasi peserta didik dalm kegiatan pembelajaran.

Bercerita mempu mengembangkan kemampuan berbicara anak di sekolah dengan langkah - langkah sebagai berikut:a) peserta didik mengatur posisi duduknya , b) anak memperhatikan guru, c) peserta didik termotivasi untuk mendengarkan cerita, d) anak di berikan kesempatan untuk memberi judul cerita, e) mendengarkan judul cerita, f) mulai storytelling, g) setelah selesai storytelling anak memberikan kesimpulan isi cerita, h) guru melengkapi kesimpulan cerita dari peserta didik.

Dalam Kamus Besar Bahasa

Indonesia (2001: 1180) keterampilan adalah kecakapan untuk menyelesaikan tugas(Sufriadi, 2015). Dapat disimpulkan bahwa keterampilan adalah kemampuan peserta didik dalam melakukan berbagai aktivitas dalam usahanya untuk menyelesaikan tugasnya. Keterampilan tersebut perlu dilatih kepada peserta didik sejak dini supaya di masa yang akan datang peserta didik akan tumbuh menjadi generasi yang terampil dan cekatan dalam melakukan segala aktivitas, dan mampu menghadapi permasalahan dalam hidup mereka.

Definisi berbicara juga dikemukakan oleh Brown dan Yule (Tambunan, 2017). Berbicara adalah kemampuan mengucapkan bunyi - bunyi bahasa untuk mengekspresikan atau menyampaikan pikiran, gagasan atau persaan secara lisan.

Tujuan utama berbicara adalah untuk dapat berkomunikasi dengan baik. Komunikasi merupakan pengiriman dan penerimaan pesan atau berita antara dua orang atau lebih sehingga pesan yang dimaksud dapat dipahami. Oleh karena itu, agar dapat menyampaikan pesan secara lebih efektif, pembicara juga harus memahami apa yang akan disampaikan atau dikomunikasikan.

TIM LBB SSC Intersolusi ( 2006:84) berpendapat tujuan dari berbicara yakninya 
1041 Penerapan Storytelling untuk meningkatkan keterampilan berbicara di Sekolah DasarDesmarita Khairoes, Taufina

untuk: 1) memberitahukan sesuatu kepada pendengar, 2) meyakinkan atau mempengaruhi pendengar, serta 3) menghibur pendengar.

Berdasarkan pendapat dari para ahli di atas, dapat disimpulkan bahwa tujuan dari berbicara secara khusus adalah untuk dapat berkomunikasi. Sedangkan tujuan berbicara secara umum ialah untuk memberitahukan atau melaporkan informasi kepada penerima informasi, meyakinkan ataupun mempengaruhi penerima informasi, untuk menghibur, serta menghendaki reaksi atau tanggapan dari pendengar itu sendiri.

Storytelling ( bercerita atau mendongeng) adalag suatu rangkaian dari sebuah strategi yang lebih sistematis berisi aktivitas dari pemindahan cerita yaitu dari pencerita kepada si pendengar(Soesilo, 2018).

Subyanto menjelaskan bahwa bercerita adalah serangkaian dari strategi yang sifatnya sitematis berupa aktivitas pemindahan cerita dari pencerita kepada pendengar(Winarsih \& Martani, 2018). Pengetahuan yang terbentuk pada peserta didik mengenai bentuk, atau karakter dari berbagai tokoh dapat dihasilkan dari mendengarkan cerita yang dituturkan oleh pencerita itu sendiri.

Whitehead mengemukakan bahwa storytelling adalah suatu kejadian baik yang nyata maupun imajinasi yang telah disususn untuk disampaikan atau dibagikan kepada orang lain. Bercerita berarti menekankan narasi bahwa seseorang mengatakan kepada orang lain tentang suatu peristiwa atau kejadian.

Selanjutnya Jennings juga menjelaskan bahwa storytelling adalah suatu seni yang tidak dibatasi oleh waktu dan budaya. Bercerita juga merupakan alat untuk menyampaikan pengetahuan, perasaan, pikiran dan ide.

Menurut Cameron bahwa Storytelling merupakan suatu kegiatan lisan yang telah dirancang tidak hanya untuk didengarkan akan tetapi juga terlibat di dalamnya. Oleh sebab itu melalui bercerita ini para peserta didik dapat berfantasi dan menerima kesan - kesan yang membuat jiwanya menjadi aktif. Berdasarkan pendapat dari para ahli di atas peneliti dapat menyimpulkan melalui storytelling ini di harapkan akan dapat membantu memberikan sebuah pengalaman yang menarik bagi peserta didik sehingga peserta didik mampu untuk menceritakan kembali cerita yang telah didengarnya dalam rangka peningkatan kemampuan berbicara peserta didik dan kemudian memperoleh nilai yang bermakna dari isi sebuah cerita.

\section{METODE}

Penelitian yang digunakan peneliti adalah Metode Penelitian Tindakan Kelas. Dan metode ini terdidri dari tahapan yang bersiklus. Tiap siklus dilakukan beberapa tahapan, yakni: a) perencanaan tindakan, b) pelaksanaan tindakan, c) observasi, d) refleksi. Pelaksanaan tindakan ini dilakukan dalam siklus berulang. Setiap pelaksanaan dilakukan 
1042 Penerapan Storytelling untuk meningkatkan keterampilan berbicara di Sekolah DasarDesmarita Khairoes, Taufina

sesuai dengan RPP ysng telah disiapkan. Model ini mengacu pada memodifikasi giagram yang mencantumkan Kemmis dan Mc Tanggart ( Depdiknas, 2005: 6), seperti pada gambar. Pada model penelitian ini, tindakan (acting) dan obsevasi ( observing) dijadikan sebagai satu kesatuan karena kedua komponenya merupakan dua kegiatan yang tidak bisa dipisahkan.

Teknik pengumpulan data yang digunakan dalam penelitian ini adalah observasi, wawancara dan dokumentasi. Analisis data berupa analisis darta kuantitatif dan analisis data kualitatif. Analisis data kuantitatif barupa hasil observasi dalam bentuk tabel data dan grafik. Sedangkan pada analisis data kualitatif dilakukan dengan cara mereduksi data, display data dan penarikan kesimpulan.

\section{HASIL DAN PEMBAHASAN}

Kegiatan yang dilakukan pada tahap ini adalah observasi di kelas I SD Negeri 02 Koto Tangah Batu Ampa. Rata - rata yang didapat dari hasil belajar siswa adalah 60,82. Berdasarkan data yang diambil dari Wali Kelas I SD Negeri 02 Koto Tangah Batu Ampa menyatakan bahwa nilai belajar klasikal anak yang belum tuntas mencapai 52\%. Hal inilah yang menyebabkan keterampilan berbicara peserta didik masih rendah. Para peserta didik masih banyak uang malu dan takut untuk sekedar bertanya ataupun mengeluarkan pendapat mereka. Penggunaan bahasa mereka sangat kental sekali, dalam kehidupan sehari - hari peserta didik menggunkan bahasa IBU ( bahasa Minang Kabau). Oleh sebab itu banyak peserta didik kurang mampu berkomunikasi dengan baik, mencampur aduklan antara bahsa Indonesia dengan bahasa daerah.

Tabel 1. Hasil skor siswa

\begin{tabular}{|c|c|c|c|c|c|c|}
\hline $\begin{array}{l}\mathrm{N} \\
\mathrm{o}\end{array}$ & Nama & $\begin{array}{l}\mathrm{L} / \\
\mathrm{P}\end{array}$ & $\begin{array}{l}\text { Skor } \\
\text { Idea } \\
1\end{array}$ & $\begin{array}{l}\text { Juml } \\
\text { ah } \\
\text { skor } \\
\text { pero } \\
\text { leha } \\
\text { n }\end{array}$ & $\begin{array}{l}\% \\
\text { Daya } \\
\text { Serap }\end{array}$ & $\begin{array}{l}\text { Ketera } \\
\text { ngan }\end{array}$ \\
\hline 1 & $\begin{array}{l}\text { Afifa Galuh } \\
\text { Fatiha }\end{array}$ & $\mathrm{P}$ & 100 & 5,3 & 5,3 & $\mathrm{TT}$ \\
\hline 2 & $\begin{array}{l}\text { Alhtaf Fitrah } \\
\text { Janksie }\end{array}$ & $\mathrm{L}$ & 100 & 4,1 & 4,1 & $\mathrm{TT}$ \\
\hline 3 & $\begin{array}{l}\text { Anisa } \\
\text { Nabillah } \\
\text { Marfi }\end{array}$ & $\mathrm{P}$ & 100 & 6,9 & 6,9 & $\mathrm{~T}$ \\
\hline 4 & $\begin{array}{l}\text { Arsya } \\
\text { Rahmanda } \\
\text { Putri }\end{array}$ & $\mathrm{P}$ & 100 & 5,0 & 5,0 & TT \\
\hline 5 & Asha Sharieza & $\mathrm{P}$ & 100 & 6,6 & 6,6 & $\mathrm{~T}$ \\
\hline 6 & $\begin{array}{l}\text { Bella Zahra } \\
\text { Maharani }\end{array}$ & $\mathrm{P}$ & 100 & 6,6 & 6,6 & $\mathrm{~T}$ \\
\hline 7 & $\begin{array}{l}\text { Chantika } \\
\text { Rosady }\end{array}$ & $\mathrm{P}$ & 100 & 6,9 & 6,9 & $\mathrm{~T}$ \\
\hline 8 & $\begin{array}{l}\text { Chelsea Okta } \\
\text { Valencia }\end{array}$ & $\mathrm{P}$ & 100 & 6,9 & 6,9 & $\mathrm{~T}$ \\
\hline 9 & $\begin{array}{ll}\text { Dinda } & \text { Putri } \\
\text { Seriena } & \\
\end{array}$ & $\mathrm{P}$ & 100 & 5,3 & 5,3 & TT \\
\hline 10 & $\begin{array}{ll}\text { Difa } & \text { Okta } \\
\text { Yudha } & \end{array}$ & $\mathrm{L}$ & 100 & 5,3 & 5,3 & TT \\
\hline 11 & $\begin{array}{l}\text { Elfira Agustin } \\
\text { Fania }\end{array}$ & $\mathrm{P}$ & 100 & 6.9 & 6.9 & $\mathrm{~T}$ \\
\hline 12 & $\begin{array}{l}\text { Farhan } \\
\text { Ghiffary }\end{array}$ & $\mathrm{L}$ & 100 & 5,6 & 5,6 & $\mathrm{TT}$ \\
\hline 13 & $\begin{array}{ll}\text { Fasya } & \text { Putri } \\
\text { Tiana } & \end{array}$ & $\mathrm{P}$ & 100 & 7,8 & 7,8 & $\mathrm{~T}$ \\
\hline 14 & Fitri Arifah & $\mathrm{P}$ & 100 & 6,9 & 6,9 & $\mathrm{~T}$ \\
\hline 15 & $\begin{array}{l}\text { Fitria Indra } \\
\text { Yelti }\end{array}$ & $\mathrm{P}$ & 100 & 5,0 & 5,0 & TT \\
\hline 16 & $\begin{array}{l}\text { Ghina } \\
\text { Kutimala }\end{array}$ & $\mathrm{P}$ & 100 & 7,8 & 7,8 & $\mathrm{~T}$ \\
\hline 17 & $\begin{array}{l}\text { Hanifah Aulia } \\
\text { Nabilla }\end{array}$ & $\mathrm{P}$ & 100 & 5,3 & 5,3 & TT \\
\hline 18 & $\begin{array}{ll}\text { Haviza } & \text { Joya } \\
\text { Rigeri } & \end{array}$ & $\mathrm{P}$ & 100 & 4,8 & 4,8 & TT \\
\hline 19 & $\begin{array}{l}\text { Igo Cikal } \\
\text { Muharam }\end{array}$ & $\mathrm{L}$ & 100 & 6,6 & 6,6 & $\mathrm{~T}$ \\
\hline 20 & $\begin{array}{l}\text { Khairani } \\
\text { Ramadhani }\end{array}$ & $\mathrm{P}$ & 100 & 5,8 & 5,8 & TT \\
\hline 21 & $\begin{array}{l}\text { Luthfi Diona } \\
\text { Pratama }\end{array}$ & $\mathrm{L}$ & 100 & 6,8 & 6,8 & $\mathrm{~T}$ \\
\hline 22 & $\begin{array}{l}\text { M. Ikhwanul } \\
\text { Arif }\end{array}$ & $\mathrm{L}$ & 100 & 5,6 & 5,6 & $\mathrm{TT}$ \\
\hline
\end{tabular}


1043 Penerapan Storytelling untuk meningkatkan keterampilan berbicara di Sekolah DasarDesmarita Khairoes, Taufina

\begin{tabular}{|c|l|l|l|l|l|l|}
\hline 23 & $\begin{array}{l}\text { M.Rizki } \\
\text { Miftha } \\
\text { Alhamid }\end{array}$ & L & 100 & 7,6 & 7,6 & T \\
\hline 24 & $\begin{array}{l}\text { Muhammad } \\
\text { Iqbal }\end{array}$ & L & 100 & 6,6 & 6,6 & T \\
\hline 25 & $\begin{array}{l}\text { Muhammad } \\
\text { Wefi Delin }\end{array}$ & L & 100 & 7,5 & 7,5 & T \\
\hline
\end{tabular}

Keterangan $: \mathrm{T}=$ Tuntas, $\mathrm{TT}=$ Tidak Tuntas

Berdasarkan hasil obsevasi aktivitas guru menunjukkan jumlah skor yang diperoleh dari semua item penilaian adalah 10 dari 16 skor total dan persentasi rata - rata $62,5 \%$ dengan kriteria cukup. Hasil yang diperoleh belum mencapai indikator yang telah ditetapkan, sehingga guru masih perlu meningkatkan aktivitas peserta didik.

Tabel 2. Analisis Tes Tindakan Siklus I

\begin{tabular}{|c|c|c|c|c|c|c|}
\hline $\begin{array}{l}\mathrm{N} \\
\mathrm{o}\end{array}$ & Nama & $\begin{array}{l}\mathrm{L} \\
/ \\
\mathrm{P}\end{array}$ & $\begin{array}{l}\text { Skor } \\
\text { Idea } \\
1\end{array}$ & $\begin{array}{l}\text { Jumla } \\
\mathrm{h} \text { skor } \\
\text { perole } \\
\text { han }\end{array}$ & $\begin{array}{l}\% \\
\text { Daya } \\
\text { Serap }\end{array}$ & $\begin{array}{l}\text { Kete } \\
\text { rang } \\
\text { an }\end{array}$ \\
\hline 1 & $\begin{array}{l}\text { Afifa Galuh } \\
\text { Fatiha }\end{array}$ & $\mathrm{P}$ & 100 & 5,3 & 5,3 & $\mathrm{TT}$ \\
\hline 2 & $\begin{array}{l}\text { Alhtaf } \\
\text { Fitrah } \\
\text { Janksie }\end{array}$ & $\mathrm{L}$ & 100 & 4,1 & 4,1 & $\mathrm{TT}$ \\
\hline 3 & $\begin{array}{l}\text { Anisa } \\
\text { Nabillah } \\
\text { Marfi } \\
\end{array}$ & $\mathrm{P}$ & 100 & 6,9 & 6,9 & $\mathrm{~T}$ \\
\hline 4 & $\begin{array}{l}\text { Arsya } \\
\text { Rahmanda } \\
\text { Putri }\end{array}$ & $\mathrm{P}$ & 100 & 5,0 & 5,0 & TT \\
\hline 5 & $\begin{array}{l}\text { Asha } \\
\text { Sharieza }\end{array}$ & $\mathrm{P}$ & 100 & 6,6 & 6,6 & $\mathrm{~T}$ \\
\hline 6 & $\begin{array}{l}\text { Bella Zahra } \\
\text { Maharani }\end{array}$ & $\mathrm{P}$ & 100 & 6,6 & 6,6 & $\mathrm{~T}$ \\
\hline 7 & $\begin{array}{l}\text { Chantika } \\
\text { Rosady }\end{array}$ & $\mathrm{P}$ & 100 & 6,9 & 6,9 & $\mathrm{~T}$ \\
\hline 8 & $\begin{array}{l}\text { Chelsea } \\
\text { Okta } \\
\text { Valencia }\end{array}$ & $\mathrm{P}$ & 100 & 6,9 & 6,9 & $\mathrm{~T}$ \\
\hline 9 & $\begin{array}{l}\text { Dinda Putri } \\
\text { Seriena }\end{array}$ & $\mathrm{P}$ & 100 & 5,3 & 5,3 & TT \\
\hline 10 & $\begin{array}{l}\text { Difa Okta } \\
\text { Yudha }\end{array}$ & $\mathrm{L}$ & 100 & 5,3 & 5,3 & TT \\
\hline 11 & $\begin{array}{l}\text { Elfira } \\
\text { Agustin } \\
\text { Fania } \\
\end{array}$ & $\mathrm{P}$ & 100 & 6.9 & 6.9 & $\mathrm{~T}$ \\
\hline 12 & $\begin{array}{l}\text { Farhan } \\
\text { Ghiffary }\end{array}$ & $\mathrm{L}$ & 100 & 5,6 & 5,6 & TT \\
\hline 13 & $\begin{array}{l}\text { Fasya Putri } \\
\text { Tiana }\end{array}$ & $\mathrm{P}$ & 100 & 7,8 & 7,8 & $\mathrm{~T}$ \\
\hline 14 & Fitri Arifah & $\mathrm{P}$ & 100 & 6,9 & 6,9 & $\mathrm{~T}$ \\
\hline 15 & Fitria Indra & $\mathrm{P}$ & 100 & 5,0 & 5,0 & TT \\
\hline
\end{tabular}

\begin{tabular}{|c|l|l|l|l|l|l|}
\hline 16 & Yelti & & & & & \\
\hline $\begin{array}{l}\text { Ghina } \\
\text { Kutimala }\end{array}$ & $\mathrm{P}$ & 100 & 7,8 & 7,8 & $\mathrm{~T}$ \\
\hline 17 & $\begin{array}{l}\text { Hanifah } \\
\text { Aulia } \\
\text { Nabilla }\end{array}$ & $\mathrm{P}$ & 100 & 5,3 & 5,3 & $\mathrm{TT}$ \\
\hline 18 & $\begin{array}{l}\text { Haviza Joya } \\
\text { Rigeri }\end{array}$ & $\mathrm{P}$ & 100 & 4,8 & 4,8 & $\mathrm{TT}$ \\
\hline 19 & $\begin{array}{l}\text { Igo Cikal } \\
\text { Muharam }\end{array}$ & $\mathrm{L}$ & 100 & 6,6 & 6,6 & $\mathrm{~T}$ \\
\hline 20 & $\begin{array}{l}\text { Khairani } \\
\text { Ramadhani }\end{array}$ & $\mathrm{P}$ & 100 & 5,8 & 5,8 & $\mathrm{TT}$ \\
\hline 21 & $\begin{array}{l}\text { Luthfi } \\
\text { Diona } \\
\text { Pratama }\end{array}$ & $\mathrm{L}$ & 100 & 6,8 & 6,8 & $\mathrm{~T}$ \\
\hline 22 & $\begin{array}{l}\text { M. } \\
\text { Ikhwanul } \\
\text { Arif }\end{array}$ & $\mathrm{L}$ & 100 & 5,6 & 5,6 & $\mathrm{TT}$ \\
\hline 23 & $\begin{array}{l}\text { M.Rizki } \\
\text { Miftha } \\
\text { Alhamid }\end{array}$ & $\mathrm{L}$ & 100 & 7,6 & 7,6 & $\mathrm{~T}$ \\
\hline 24 & $\begin{array}{l}\text { Muhammad } \\
\text { Iqbal }\end{array}$ & $\mathrm{L}$ & 100 & 5,6 & 5,6 & $\mathrm{TT}$ \\
\hline 25 & $\begin{array}{l}\text { Muhammad } \\
\text { Wefi Delin }\end{array}$ & $\mathrm{L}$ & 100 & 7,5 & 7,5 & $\mathrm{~T}$ \\
\hline
\end{tabular}

Berdasarkan analisis di atas, skor ratarata sudah menunjukkan peningkatan dari hasil belajar sebelum di adakan penelitian 52\%, yaitu sebesar $8 \%$. Presentase tumtas klasikal yang diperoleh setelah penelitian yaitu sebesa $60 \%$, belum mencapai presentase ketuntasan yang telah ditetapkan oleh sekolah yaitu $70 \%$.

Pelaksanaan pada siklus II tidaklah jauh berbeda dengan siklus I, hanya saja beberapa hal yang di anggap kurang pada siklus I diperbaiki pada siklus II.

Tabel 3. Analisis Tes Tindakan Siklus II

\begin{tabular}{|l|l|l|l|l|l|l|}
\hline $\begin{array}{l}\text { N } \\
\text { o }\end{array}$ & Nama & $\begin{array}{l}\text { L/ } \\
\text { P }\end{array}$ & $\begin{array}{l}\text { Skor } \\
\text { Idea } \\
1\end{array}$ & $\begin{array}{l}\text { Jumla } \\
\text { h skor } \\
\text { perole } \\
\text { han }\end{array}$ & $\begin{array}{l}\% \\
\text { Daya } \\
\text { Sera } \\
\text { p }\end{array}$ & $\begin{array}{l}\text { Ket } \\
\text { eran } \\
\text { gan }\end{array}$ \\
\hline 1 & $\begin{array}{l}\text { Afifa Galuh } \\
\text { Fatiha }\end{array}$ & $\mathrm{P}$ & 100 & 7,3 & 7,3 & $\mathrm{~T}$ \\
\hline 2 & $\begin{array}{l}\text { Alhtaf Fitrah } \\
\text { Janksie }\end{array}$ & $\mathrm{L}$ & 100 & 7,1 & 7,1 & $\mathrm{~T}$ \\
\hline 3 & $\begin{array}{l}\text { Anisa } \\
\text { Nabillah } \\
\text { Marfi }\end{array}$ & $\mathrm{P}$ & 100 & 6,9 & 6,9 & $\mathrm{~T}$ \\
\hline 4 & $\begin{array}{l}\text { Arsya } \\
\text { Rahmanda } \\
\text { Putri }\end{array}$ & $\mathrm{P}$ & 100 & 7,0 & 7,0 & $\mathrm{~T}$ \\
\hline 5 & Asha Sharieza & $\mathrm{P}$ & 100 & 6,3 & 6,3 & $\mathrm{~T}$ \\
\hline
\end{tabular}


1044 Penerapan Storytelling untuk meningkatkan keterampilan berbicara di Sekolah DasarDesmarita Khairoes, Taufina

\begin{tabular}{|c|c|c|c|c|c|c|}
\hline 6 & $\begin{array}{l}\text { Bella Zahra } \\
\text { Maharani }\end{array}$ & $\mathrm{P}$ & 100 & 6,3 & 6,3 & $\mathrm{~T}$ \\
\hline 7 & $\begin{array}{l}\text { Chantika } \\
\text { Rosady }\end{array}$ & $\mathrm{P}$ & 100 & 6,3 & 6,3 & $\mathrm{~T}$ \\
\hline 8 & $\begin{array}{l}\text { Chelsea Okta } \\
\text { Valencia }\end{array}$ & $\mathrm{P}$ & 100 & 6,9 & 6,9 & $\mathrm{~T}$ \\
\hline 9 & $\begin{array}{ll}\text { Dinda } & \text { Putri } \\
\text { Seriena } & \\
\end{array}$ & $\mathrm{P}$ & 100 & 6,6 & 6,6 & $\mathrm{~T}$ \\
\hline 10 & $\begin{array}{ll}\text { Difa } & \text { Okta } \\
\text { Yudha } & \end{array}$ & $\mathrm{L}$ & 100 & 6,6 & 6,6 & $\mathrm{~T}$ \\
\hline 11 & $\begin{array}{l}\text { Elfira Agustin } \\
\text { Fania }\end{array}$ & $\mathrm{P}$ & 100 & 6.9 & 6.9 & $\mathrm{~T}$ \\
\hline 12 & $\begin{array}{l}\text { Farhan } \\
\text { Ghiffary }\end{array}$ & $\mathrm{L}$ & 100 & 5,6 & 5,6 & TT \\
\hline 13 & $\begin{array}{ll}\text { Fasya } & \text { Putri } \\
\text { Tiana }\end{array}$ & $\mathrm{P}$ & 100 & 7,8 & 7,8 & $\mathrm{~T}$ \\
\hline 14 & Fitri Arifah & $\mathrm{P}$ & 100 & 6,9 & 6,9 & $\mathrm{~T}$ \\
\hline 15 & $\begin{array}{l}\text { Fitria Indra } \\
\text { Yelti }\end{array}$ & $P$ & 100 & 5,0 & 5,0 & TT \\
\hline 16 & $\begin{array}{l}\text { Ghina } \\
\text { Kutimala }\end{array}$ & $\mathrm{P}$ & 100 & 7,8 & 7,8 & $\mathrm{~T}$ \\
\hline 17 & $\begin{array}{l}\text { Hanifah Aulia } \\
\text { Nabilla }\end{array}$ & P & 100 & 6,6 & 6,6 & $\mathrm{~T}$ \\
\hline 18 & $\begin{array}{l}\text { Haviza Joya } \\
\text { Rigeri }\end{array}$ & $P$ & 100 & 6,8 & 6,8 & TT \\
\hline 19 & $\begin{array}{l}\text { Igo Cikal } \\
\text { Muharam }\end{array}$ & $\mathrm{L}$ & 100 & 6,3 & 6,3 & $\mathrm{~T}$ \\
\hline 20 & $\begin{array}{l}\text { Khairani } \\
\text { Ramadhani }\end{array}$ & $\mathrm{P}$ & 100 & 6,8 & 6,8 & $\mathrm{~T}$ \\
\hline 21 & $\begin{array}{l}\text { Luthfi Diona } \\
\text { Pratama }\end{array}$ & L & 100 & 6,6 & 6,6 & $\mathrm{~T}$ \\
\hline 22 & $\begin{array}{l}\text { M. Ikhwanul } \\
\text { Arif }\end{array}$ & $\mathrm{L}$ & 100 & 7,6 & 7,6 & $\mathrm{~T}$ \\
\hline 23 & $\begin{array}{l}\text { M.Rizki } \\
\text { Miftha } \\
\text { Alhamid }\end{array}$ & $\mathrm{L}$ & 100 & 7,6 & 7,6 & $\mathrm{~T}$ \\
\hline 24 & $\begin{array}{l}\text { Muhammad } \\
\text { Iqbal }\end{array}$ & $\mathrm{L}$ & 100 & 6,8 & 6,8 & $\mathrm{~T}$ \\
\hline 25 & $\begin{array}{l}\text { Muhammad } \\
\text { Wefi Delin }\end{array}$ & $\mathrm{L}$ & 100 & 6,5 & 6,5 & $\mathrm{~T}$ \\
\hline
\end{tabular}

Penerapan Storytelling dalam pembelajaran Bahasa Indonesia sesuai dengan hasil penelitian yang dilaksanakan dalam dua siklus dapat meningkatkan hasili belajar para peserta didik pada kelas I SD Negeri 02 Koto Tangah Batu Ampa. Berdasarkan penelitan ini telah menunjukkan bahwa pada kelas rendah memanglah belajar sambil bermain. Dan berdasarkan data yang diambil dapat disimpulkan bahwa penerapan Storytelling ini dapat meningkatkan keterampilan berbicara peserta didik terutama di kelas rendah.

Penerapan Storytelling telah menunjukkan bahwa hasil belajar siswa dapat meningkat. Dan dari data juga menunjukkan bahwa siklus I peserta didik sudah menunjukkan peningkatan hasil belajarnya dari 60,82 menjadi 64,28 meskipun belum mencapai KKM yang telah di tetapkan yaitu 65. Penerapan Storytelling ini dianggap baik maka dilakukanlah siklus II dalam rangka meningkatkan hasil belajar peserta didik. Dan hasilnyatelah membuktikan bahwa terdapat Berdasarkan hasil evaluasi pelaksanaan tindakan siklus II bahwa motivasi peserta didik dalam kegiatan pembelajaran sangat baik, dan peserta didik lebih aktifdalam mendengarkan guru mengajar. Dan juga terlihat pada siklus II ini hanya 3 orang peserta didik saja yang tidak tuntas perolehannya. Hal tersebut menunjukkan terdapat peningkatan presentase perolehan dari siklus I ke siklus II, yaitu $64,28 \%$ pada siklus I menjadi $79,94 \%$ pada siklus II atau kenaikannya apabila di presentasekan sebesar 15,66\%.

kenaikan 15\% dari Siklus I yaitu antara 64,28 menjadi 79.94. peningkatan ini adalah hasil belajar peserta didik dari siklus I ke siklus II telah mengalami peningkatan.

Terdapat 3 peserta didik yang belum tuntas. Hal ini di sebabkan ketiga peserta didik tersebut mempunyai kekurangan daya tangkap dan masih malu berbicara di depan kelas. Berdasarkan data di atas dapat peneliti simpulkan bahwa keterampilan berbicara melalui penerapan storytelling dapat meningkatkan hasil belajar peserta didik. Penerapan Storytelling ini dapat 
1045 Penerapan Storytelling untuk meningkatkan keterampilan berbicara di Sekolah DasarDesmarita Khairoes, Taufina

meningkatkan perhatian peserta didik, dan merangsang para peserta didik untuk lebih aktif dalam proses belajar di dalam kelas

\section{SIMPULAN}

Berdasarkan hasil dan pembahasan, maka dapat peneliti simpulkan bahwa penerapan storytelling dapat meningkatkan keterampilan berbicara pada peserta didik di kelas I SD Negari 02 Koto Tangah Batu Ampa, serta dapat meningkatkan aktivitas belajar peserta didik. Selain hal itu keterampilan berbicara dapat ditingkatkan melalui penerapan storytelling, dengan hasil belajar peserta didik dari 60,82(nilai rata - rata hasil belajar sebelum penelitian) menjadi 64,28 (siklus I) dan 79,94 ( siklus II). Begitupun pada ketuntasan klasikal meningkat dari ketuntasan $60 \%$ pada siklus I menjadi 88\% pada siklus II. Demikian peningkatan daya serap klasikal dari $64,28 \%$ pada siklus I minjadi 79,94\% pada siklus II.

Guru diharapkan lebih banyak memberikan kesempatan pada peserta didik untuk mengembangkan keterampilan berbicara Anak - anak harus di kenalkan dengan berbagai macam cerita atau storytelling agar dapat merangsang otak peserta didik dan mengasah keterampilan berbicara pada diri peserta didik

\section{DAFTAR PUSTAKA}

Aji, W. N., \& Budiyono, S. (2018). International Journal of Active Learning The Teaching Strategy of Bahasa Indonesia in Curriculum 2013. International Journal of Active Learning, $3(2), 58-64$.

Arikunto, Suharsimi. 2010. Prosedur

Penelitian Suatu Pendekatan Praktik. Jakarta: PT Rineka Cipta.

Anwar, Ruminiati, S. (2017). Pembelajaran Tematik Terpadu. Cendekia, (978-60271836-6-7), 1005-1013. Retrieved from Mohfaridnurulanwar.

Eko. (2016). Peningkatan Keterampilan Berbicara Melalui Metode Storytelling (Bercerita) Dengan Menggunakan Boneka Tangan Pada Mata Pelajaran Bahasa Indonesia Siswa Kelas V Sd Negeri Teloyo 3. Naskah Publikasi Ilmiah, 2(4), 4-5.

Machali, I. (2015). Kebijakan Perubahan Kurikulum 2013 dalam Menyongsong Indonesia Emas Tahun 2045. Jurnal Pendidikan Islam, 3(1), 71. https://doi.org/10.14421/jpi.2014.31.7194

Soesilo, dkk. (2018). Meningkatkan Kemampuan Berbicara Anak Usia 5-6 Tahun Melalui Digital Storytelling Di Tk Apple Kids Salatiga Apple Kids Salatiga terlihat kesulitan di aspek fonologis . Seperti, ketika masih ada yang kurang jelas atau perlu keterlambatan ini berdampak pad. Pendidikan Usia Dini, 12(1), 1-11.

Sufriadi. (2015). Pembelajaran Bahasa Indonesia Kelas Rendah Di Sekolah Dasar Islam Sabilal Muhtadin Banjarmasin (the Learning of Indonesian of Low Class At Islamic Primary School of Sabilal Muhtadin Banjarmasin). Jurnal Bahasa, Satra, Dan Pembelajarannya, 5(1), 81-93. Retrieved from http://ppjp.unlam.ac.id/journal/index.php /jbsp 
1046 Penerapan Storytelling untuk meningkatkan keterampilan berbicara di Sekolah DasarDesmarita Khairoes, Taufina

Tambunan, P. (2017). Pembelajaran Keterampilan Berbicara Di Sekolah Dasar. The British Journal of Psychiatry, 112(483),

211-212. https://doi.org/10.1192/bjp.112.483.211-

a

Winarsih, T., \& Martani, W. (2018). Storytelling Using Wayang Kancil To Enhance the Understanding of Prosocial Behavior for Preschool Children. SOSIOHUMANIORA: Jurnal Ilmiah Ilmu Sosial Dan Humaniora, 4(1), 2336.

https://doi.org/10.30738/sosio.v4i1.2214

Zainal Abidin. (2018). Peningkatan kemampuan berbicara pembelajaran bahasa indonesia dengan teknik bercerita ( story telling ) pada sekolah dasar. 1(1), 3-13.

Zuhriyah, M. (2017). Storytelling to Improve Students' Speaking Skill. English Education: Jurnal Tadris Bahasa Inggris, 10(1), 119-134. Retrieved from http://ejournal.radenintan.ac.id/index.php /ENGEDU/article/view/879/753 
1006 Penerapan Storytelling untuk meningkatkan keterampilan berbicara di Sekolah DasarDesmarita Khairoes, Taufina 